\title{
ANATOMI ZAKAT MAL (ANTARA IBADAH MAHDHAH DAN MU'AMALAH MALIYYAH)
}

\author{
Rusdan \\ IAI Nurul Hakim Kediri \\ rusdan1983@gmail.com
}

\begin{abstract}
There is a general view that is developing among the jurists' that zakat is a mahdhah worship which contains the side of mu'amalh maliyah ijtima'iyyah. As a mahdhah worship, rakat is ta'abbudi. At this point, submission and obedience are put forward so that there is no room for innovation and creation. While in its position as mu'amalh maliyah ijtima'iyyah it is ta'aqquli, so it is possible to make innovations and creations, both regarding the object of zakat, miqdar zakat (nishab and percentage of zakat), or other things that surround the zakat. The data used in this research is secondary data which is collected and obtained from literature studies, documents and other scientific publications. While the data analysis method used is a qualitative descriptive method, which is intended to comprehensively explain and analyze the position of zakat as mahdhah worship which contains mu'amalah maliyyah ijtima'iyyah which cannot be separated from the socio-economic aspects. Although it is understood that zakat mal contains aspects of mu'amalah maliyah ijtima'yyah, in addition to aspects of mabdhah worship which are ritual nuances and are ta' aqquli in nature, in practice the nuances of worship are more dominant, both at the theoretical-normative and practicalpolicy level. This is evident from the lack of progressive ijtihad to develop zakat miqdar (nishab and zakat percentage), zakat objects, and state policies. So far, the object of zakat has almost no development other than what the jurists have discussed in figh books which usually only revolves around a few commodities / business fields, such as zakat on gold and silver, zakat on livestock (usually limited to camels, cows, and goat), zakat on agriculture and certain fruits, zakat on commerce, and zakeat for mining goods and bidden assets.
\end{abstract}

Keywords: Zakat Mal, Mabdhah Worship, Mu'amalah Maliyah Ijtima'iyyah

\begin{abstract}
Abstrak : Terdapat pandangan umum yang berkembang di kalangan fuqaha' bahwa zakat merupakan ibadah mahdhah yang mengandung sisi mu'amalh maliyah ijtima'iyyah. Sebagai ibadah mahdhah, zakat bersifat ta'abbudi. Pada titik ini yang dikedepankan adalah ketundukan dan kepatuhan sehingga tidak boleh ada ruang inovasi dan kreasi. Sementara dalam posisinya sebagai mu'amalh maliyah ijtima'iyyah bersifat ta'aqquli, sehingga sangat mungkinkan melakukan inovasi dan kreasi, baik menyangkut objek zakat, miqdar zakat (nishab dan persentase zakat), ataupun hal lain yang mengitari zakat itu. Data yang digunakan dalam penelitian ini adalah data sekunder yang dihimpun dan diperoleh dari studi literatur, dokumen dan publikasi ilmiah lainnya. Sementara metode analisis data yang dipakai adalah metode deskriptif kualitatif, yang mana hal itu dimaksudkan untuk menjelaskan dan menganalisis secara konprehensif mengenai kedudukan zakat sebagai ibadah mahdhah yang bermuatan mu'amalah maliyyah ijtima'iyyah yang tak terlepas dari aspek sosial ekonomi. Meski telah dipahami bahwa zakat mal mengandung aspek mu'amalah maliyah ijtima'yyah, di samping aspek ibadah mahdhah yang bernuansa ritual dan bersifat ta'aqquli, namun dalam praktiknya nuansa ibadahnya lebih dominan, baik dalam tataran teoritis-normatif maupun
\end{abstract}


praktis-kebijakan. Hal ini tampak dari kurangnya ijtihad progresif untuk mengembangkan miqdar zakat (nishab dan persentase zakat), objek zakat, dan kebijakan negara. Selama ini, objek zakat nyaris tidak ada pengembangan selain dari yang telah dibahas para fuqaha' dalam kitab-kitab fiqih yang biasanya hanya berkisar pada beberapa komoditas/ bidang usaha, seperti zakat emas dan perak, zakat binatang ternak (biasanya dibatasi pada unta, sapi, dan kambing), zakat pertanian dan buah-buahan tertentu, zakat perniagaan, serta zakat barang tambang dan harta terpendam.

Kata Kunci: Zakat Mal, Ibadah Mahdhah, Mu'amalah Maliyah Ijtima’iyyah

\section{PENDAHULUAN}

Distribusi kekayaan merupakan salah satu solusi yang dapat menjamin tegaknya keadilan ekonomi bagi masyarakat. Dalam sistem ekonomi Islam, zakat merupakan Salah satu instrumen distribusi kekayaan yang bersifat obligatori. Hal ini berarti bahwa umat Islam yang memiliki harta tertentu serta telah melewati batas minimal tertentu diwajibkan untuk membayar zakat. Di mana dalam membayar zakat, tidak harus menunggu kesadaran orang yang memiliki harta benda (muzakeki). Ini karena ia merupakan sebuah kewajiban yang telah ditetapkan atas setiap Muslim yang telah memenuhi kriteria tertentu. Selain itu, negara atau pemerintah juga harus berperan aktif dalam memungut zakat dari kaum Muslim sebagaimana diterangkan dalam QS. at-Taubah (9): 103. Itulah sebabnya, Khalifah Abu Bakar memerangi orang-orang yang menolak menyerahkan sebagian hartanya untuk berzakat. ${ }^{1} \mathrm{Hal}$ ini karena zakat merupakan unsur terpenting dalam menjalankan roda perekonomian negara $^{2}$ di samping jizyah, kharaj, ushr, dan sebagainya.

Hanya saja, perlu ditegaskan bahwa tindakan khalifah pertama ini bukan tanpa hambatan dan gesekan, terutama vis a vis Umar bin Khaththab. Sebagaimana dicatat Aksin Wijaya, ${ }^{3}$ hal ini mungkin terjadi karena adanya tumpang tindih pemahaman antara agama dan pengetahuan keagamaan (wacana agama) kedua tokoh tersebut. Jika Abu Bakar sebagai kepala negara memerangi para pembangkang zakat

1 Indra Sholeh Husni, "Konsep Keadilan Ekonomi Islam dalam Sistem Ekonomi: Sebuah Kajian Konseptual," dalam Islamic Economic Journal, Vol. 6, No. 1 Juni 2020, (Ponorogo: Fakultas Ekonomi dan Manajemen Unida Gontor, 2020), hal. 69-70. Lihat juga Heri Sudarsono, Bank dan Lembaga Kenangan Syariah Deskripsi dan Ilustrasi, (Yogyakarta: Ekonisia UII, 2007), hal. 234-235.

2 Maria Ulfa Sitopu, "Zakat dan Perekonomian Umat Islam," dalam Islam Futura, Vol. VI, No. 2 Tahun 2017, (Banda Aceh: Pascasarjana UIN Ar-Raniry, 2007), hal. 52.

3 Aksin Wijaya, Ragam Jalan Memahami Islam, (Yogyakarta: IRCiSoD, 2019), hal. 50. 
karena menurut logika politik sang khalifah hal tersebut dapat melemahkan ekonomi negara, maka Umar bin Khaththab dalam kapasitasnya sebagai ulama' pada sisi lainnya justru tidak menghendaki peperangan terhadap mereka sebagaimana tidak diperanginya seseorang yang tidak mengerjakan shalat dengan tetap meyakini kewajibannya. ${ }^{4}$

Terlepas dari analisis kritis Aksin tersebut, faktanya sikap tegas Khalifah pertama pasca Rasulullah saw. itu kemudian mendapatkan legalitas penuh dari para sahabat Nabi, sehingga menjadi ijma' (kesepakatan) mereka. ${ }^{5}$

Bahkan lebih dari itu, Abu Bakar membuat keputusan tegas dan menjadi kebijakan dirinya selaku khalifah, yakni mewajibkan pembayaran zakat kepada orang yang telah mengaku tunduk kepada pemerintahan Islam, lebih khusus lagi kepada mereka yang telah membuat perjanjian dengan Nabi Muhammad saw. Kenyataan ini kemudian menjadi titik tolak bagi Joseph Schacht, seorang orientalis dan pakar hukum Islam, dalam membuat kesimpulan bahwa kebijakan zakat dalam Islam mulai melembaga pada masa Abu Bakar. Lebih lanjut ia menyatakan bahwa pada masa Nabi zakat belum atau tidak menjadi bagian dari kebijakan negara hingga datanglah masa Abu Bakar yang mempopulerkan kebijakan teresebut. Namun pendapat Schacht ini dibantah oleh Yusuf Qardhawi. Menurutnya, zakat sebagai rukun Islam telah dilaksanakan dalam bentuk kebijakan Nabi sebagai seorang pemimpin kaum Muslimin, termasuk juga dalam menetapkan pajak bagi non-Muslim. ${ }^{6}$

Diinternalisasikannya zakat ke dalam kebijakan negara pada masa Abu Bakar tidak dapat menutupi satu fakta bahwa zakat telah diwajibkan pada masa awal Islam di Makkah secara umum. Pada periode ini, jenis harta yang wajib dizakati, kadar zakat, orang-orang yang berhak menerima zakat (mustabik) belum ditentukan secara spesifik, meski mungkin prinsip asasi dari zakat itu telah ditetapkan. ${ }^{7}$ Sehingga pada

4 Perdebatan antara Abu Bakar dan Umar bin Khaththab mengenai memerangi para pembangkang zakat dapat dibaca pada Ali Muhammad ash-Shallabi, Biografi Umar bin Khattab, Terj. Ismail Jalili dan Imam Fauji, (Jakarta Timur: Beirut Publishing, 2014), hal. 91;

${ }_{5}$ Abu Bakr Jabir al-Jazairi, Ensiklopedi Muslim, Terj. Fadhli Bahri, (Jakarta Timur: Darul Falah, 2006), hal. 397. Lihat juga Abdullah ad-Dumaiji, Konsep Kepemimpinan dalam Islam, Terj. Umar Mujtahid, (Jakarta Timur: Ummul Qura, 2017), hal. 377.

${ }^{6}$ Hilman Latief, Fatwa-Fatwa Filantropi Islam di Indonesia Anotasi Komparasi dan Kompilasi, (Yogyakarta: UMY Press, 2019), hal. 34-35. hal. 154-155.

7 Sayyid Quthb, Tafsir Ayat-Ayat Riba, terj. Ali Rohmat, (Jakarta Selatan: Wali Pustaka, 2018), 
tahap ini praktik zakat dikembalikan pada sensitivitas dan kemurahan hati kaum Muslimin. Barulah kemudian pada tahun kedua hijriyah ditetapkan secara spesifik jumlah, jenis, dan perincian harta yang wajib dikeluarkan sebagai zakat. ${ }^{8}$ Pada periode ini juga Rasulullah mengutus para pengumpul zakat ke berbagai daerah dengan tugas yang jelas. Namun, pada masa ini pengumpulan zakat bukan merupakan pekerjaan yang memerlukan purnawaktu dan para petugasnya tidak diberikan gaji resmi, tetapi hanya memperoleh bayaran tertentu dari dana zakat. ${ }^{9}$

Zakat merupakan instrumen ibadah yang memiliki sisi sosial ekonomi yang sangat kuat. Dalam QS. al-Baqarah (2): 276 dan QS. ar-Rum (30): 39 ditegaskan bahwa salah satu fungsi zakat adalah sebagai antitesa dari sistem perekonomian ribawi. Sehingga upaya memerangi sistem riba tidak akan berjalan dengan baik apabila institusi zakat tidak dapat dioptimalkan. ${ }^{10}$

Zakat yang arti literalnya adalah penyucian (thaharab), pertumbuhan (nama), keberkahan (barakah), dan pujian (madh), secara teknis pada hakikatnya merupakan kewajiban finansial seorang Muslim untuk mengeluarkan sebagian kecil dari kekayaan bersih atau hasil pertaniannya yang telah melewati batas minimal (nishab) tertentu. Ia merupakan salah satu rukun Islam yang merefleksikan tekad yang kuat untuk menyucikan masyarakat dari penyakit kemiskinan, harta benda orang-orang kaya, dan pelanggaran terhadap ajaran-ajaran Islam yang terjadi karena tidak terpenuhinya kebutuhan-kebutuhan pokok bagi setiap orang. Karena itu, zakat merupakan komitmen seorang Muslim dalam bidang sosioekonomi yang tak terhindarkan untuk menjamin terpenuhinya kebutuhan pokok bagi semua orang dengan tanpa membebankan hal tersebut pada kas negara sebagaimana yang dilakukan sosialisme

8 Sayyid Sabiq, Fiqih sunnah Jilid 2, Terj. Abu Aulia dan Abu Syaukina, Jakarta: Republika Penerbit, 2017), hal. 66. Ada sementara yang berpendapat bahwa yang diwajibkan pada tahun kedua hijriyah adalah zakat fitrah. Ada pun zakat maal diwajibkan pada tahun kesembilan hijriyah, di mana pada periode tersebut kondisi perekonomian kaum Muslim telah stabil. Namun demikian, sebagian besar ahli hadits cenderung berpendapat bahwa zakat maal telah diwajibkan sebelum tahun kesembilan hijriyah. Dalam hal ini, Maulana Abul Hasan menyatakan bahwa zakat maal diwajibkan setelah peristiwa hijrah dan dalam kurun waktu lima tahun setelahnya. Uraian selengkapnya lihat Adiwarman Azwar Karim, Sejarah Pemikiran Ekonomi Islam, (Jakarta: PT. RajaGrafindo Persada, 2008), hal. 39-40.

${ }^{9}$ Adiwarman Azwar Karim, Ibid., hal. 40.

${ }^{10}$ Irfan Syauqi Beik dan Laily Dwi Arsyianti, Ekonomi Pembangunan Syariah, (Jakarta: Rajawali Pers, 2016), hal. 182. 
dan negara kesejahteraan modern. ${ }^{11}$ Konsep zakat punya hitung-hitungan sendiri dalam penyucian dan pembersihan harta benda orang-orang kaya yakni agar mereka tidak merasa terbebani. Sementara pada sisi yang lain yang miskin bisa mendapatkan sumber modal segar secara berkesinambungan. Dalam konteks ekonomi Islam ia disebut sebagai instrumen pengentasan kemiskinan dalam bentuk distribusi pendapatan. $^{12}$

Sementara itu, dalam konstruksi ilmu fikih dan hadits, zakat diposisikan sebagai pilar Islam yang ketiga. Wacana tentang zakat tidak bisa dipisahkan dari pembahasan ekonomi Islam. Zakat tidak bisa hanya dipandang dari aspek ritual semata, namun juga aspek interaksi sosial dan politik (mu'amalah maliyah dan siyasah ijtima'iyyah). Seorang wajib zakat (muzakki) tidak mungkin dapat melaksanakan kewajiban zakat tanpa adanya pihak penerima (mustabik). Antara keduanya terjalin interaksi yang didorong oleh kesadaran spritual (keimanan) dan kepekaan sosial di pihak muzakki, serta kesadaran diri dari pihak mustabik. Muqakki sebagai pihak yang memiliki kelebihan harta benda, berstatus sebagai mu'amil yang memosisikan dirinya sebagai pihak yang membantu. Sementara mustahik sebagai mu'amal, memosisikan dirinya sebagai orang yang dibantu dan suatu ketika dalam tugas-tugas rumah tangga maupun sosial, ia bisa bertindak sebagai orang yang membantu meringankan tugastugas muzakki. ${ }^{13}$ Sehingga bila zakat diterapkan secara benar dan menyeluruh, maka ia memiliki peran yang sangat esensial dalam tarbiyah ruhiyah, yang selanjutnya akan merealisasikan keadilan sosial dan melahirkan pertumbuhan ekonomi yang pesat sekaligus sehat. ${ }^{14}$

Artikel ini secara khusus mengurai tarik ulur posisi zakat sebagai ibadah mahdhah di satu sisi dan mu'amalah maliyah ijtima'iyyah pada sisi lainnya.

${ }^{11}$ M. Umer Chapra, Islam dan Tantangan Ekonomi, Terj. Ikhwan Abidin Basri, (Jakarta: Gema Insani Pres, 2006), hal. 270-271.

12 Junaidi Safitri, “Implementasi Konsep Zakat dalam Al-Qur'an Sebagai Upaya Mengentaskan Kemiskinan di Indonesia," dalam Mukaddimah: Jurnal Studi Islam, Volume 2, No. 1, Juni 2017, (Yogyakarta: Kopertais Wilayah III UIN Sunan Kalijaga Yogyakarta, 2017), hal. 21-22.

13 A. Muhyiddin Khotib, Rekonstruksi Fikih Zakat Telaah Komprehensif Fikih Zakat Pendekatan Teoritis dan Metodologi, (Malang: Literasi Nusantara, 2019), hal. 1.

${ }^{14}$ Junaidi Safitri, Op. Cit., hal. 21. 


\section{METODE PENELITIAN}

Metode analisis data yang dipakai dalam artikel ini adalah metode deskriptif kualitatif, yang mana hal itu dimaksudkan untuk menjelaskan dan menganalisis secara konprehensif mengenai kedudukan zakat sebagai ibadah mahdhah yang bermuatan mu'amalah maliyyah ijtima'izyah yang tak terlepas dari aspek sosial ekonomi. Sementara itu, data yang digunakan adalah data sekunder yang dihimpun dan diperoleh dari studi literatur, dokumen dan publikasi ilmiah serta tidak menutup kemungkinan dari internet yang relevan dengan tema artikel. Data-data tersebut kemudian diolah, dianalisis, disistematisasi hingga akhirnya disusun dalam sebuah artikel yang memenuhi standar ilmiah.

\section{PEMBAHASAN}

\section{Konsep Dasar Zakat}

Imam al-Mawardi ${ }^{15}$ menyebutkan bahwa zakat dan shadaqah adalah dua istilah yang identik. Zakat adalah shadaqah, shadaqah adalah zakat. Lebih lanjut, ia juga menegaskan bahwa zakat dipungut dari harta benda yang dimaksudkan untuk diputar dan dikembangkan, di mana ia dipungut dari jumlah pokok harta atau dari hasil perputaran harta benda itu.

Zakat adalah hak Allah berupa harta yang diberikan oleh seseorang (yang kaya) kepada orang-orang miskin. Harta itu disebut dengan zakat karena di dalamnya terkandung penyucian jiwa, pengembangannya dengan kebaikan-kebaikan, serta harapan untuk mendapatkan keberkahan. ${ }^{16}$ Berbeda dengan ibadah mahdhah lainnya semisal shalat dan puasa ramadhan, zakat termasuk dalam kategori ibadah maliyah, yakni ibadah dengan harta benda yang bertujuan untuk mewujudkan keadilan sosial, mengentaskan kemiskinan, menyebarkan rasa cinta, kasih sayang, dan saling menghormati sesama Muslim. ${ }^{17}$ Dengan begitu, zakat yang dibayarkan oleh orang kaya bukan merupakan bentuk keberpihakan kepada kaum miskin. Karena memang

15 Imam al-Mawardi, Hukum Tata Negara dan Kepemimpinan dalam Takaran Islam, Terj. Abdul Hayyie al-Kattani dan Kamaluddin Nurdin, (Jakarta: Gema Insani Press, 2000), hal. 220.

${ }^{16}$ Sayyid Sabiq, Op. Cit., hal. 64.

${ }^{17}$ Musthafa Dieb al-Bugha dan Muhyiddin Mitsu, Al-Wafi Syarah Hadis Arba'in Imam AnNawawi, terj. Rohidin Wakhid, (Jakarta: Qisthi Press, 2017), hal. 21. 
kekayaan yang dimiliki golongan kaya bukan milik riil mereka. Posisi mereka hanya sebagai pemegang amanah. Mereka harus membelanjakannya sesuai dengan ketentuan, yang paling penting salah satunya adalah memenuhi kebutuhan orangorang miskin. Pada sisi yang lain, orang miskin tidak boleh memandang penerimaan zakat sebagai perlakuan tidak baik karena apa yang mereka terima sebenarnya adalah hak mereka yang telah ditentukan oleh Allah dalam kekayaan orang-orang kaya. ${ }^{18}$

Secara lughawi, zakat berarti berkah (البركة), berkembang (الطهارة), (النماء), suci dan kebaikan (الصلاح). ${ }^{19}$ Dari sisi peristilahan, ulama' berbeda dalam mendefinisikan substansi zakat. Menurut fuqaha' Madzhab Hanafi, zakat adalah pemberian harta karena Allah kepada fakir miskin yang beragama Islam, selain Bani Hasyim atu bekas budaknya, dengan ketentuan bahwa manfaat harta itu harus terputus, dalam arti tidak mengalir lagi kepada pemiliknya yang asli dengan cara apapun.

Bagi fuqaha' Madzhab Maliki, zakat adalah mengeluarkan bagian tertentu dari harta tertentu pula, yang telah mencapai nishab, diberikan kepada yang berhak menerimanya, dengan catatan tambahan harta itu merupakan milik si pemberi sepenuhnya dan telah mencapai haul, terutama untuk selain barang tambang dan hasil pertanian.

Lebih ringkas dari dua definisi sebelumnya, para fuqaha' Madzhab Syafi'i mengatakan bahwa zakat adalah harta tertentu yang dikeluarkan dari harta tertentu dengan cara tertentu pula.

Sementara bagi fuqaha' Madzhab Hambali, yang dimaksud dengan zakat adalah hak yang wajib dikeluarkan dari suatu harta. ${ }^{20}$

Dapat juga dikatakan bahwa zakat berarti kewajiban atas sejumlah harta tertentu untuk kelompok tertentu dan dalam waktu tertentu. Hal ini berarti bahwa tidak semua harta benda yang dimiliki seseorang dapat dimasukkan sebagai objek wajib zakat. Objek wajib zakat merujuk pada beberapa komoditas seperti emas,

${ }^{18}$ M. Umer Chapra, Op. Cit., hal. 272.

${ }_{19}$ Abdul Wahid al-Faizin dan Nashr Akbar, Tafsir Ekonomi Kontemporer Menggali Teori Ekonomi dari Ayat-Ayat al-Qur'an, (Jakarta: Gema Insani Pres, 2018), hal. 101; Agus Siswanto, dkk, HRD Syariah Teori dan Implementasi, (Jakarta: Gramedia, 2020), hal. 329; Departemen Ekonomi dan Keuangan Syariah Bank Indonesia dan P3EI Fakultas Ekonomi Universitas Islam Indonesia, Pengelolaan Zakat Yang Efektif: Konsep dan Praktik di Berbagai Negara, Jakarta: Departemen Ekonomi dan Keuangan Syariah Bank Indonesia, 2016), hal. 61.

${ }^{20}$ Syauqi Ismail Sahhatih, Penerapan Zakat dalam Bisnis Modern, terj. Bahrun Abu Bakar dan Anshori Umar Sitanggal, (Bandung: Pustaka Setia, 2007), hal. 19-21. 
perak, uang, komoditas perdagangan, investasi, tambang, dan sebagainya. Sementara anak kalimat untuk kelompok tertentu mengandung makna bahwa alokasi zakat tidak boleh keluar dari kelompok tertentu yang disebut mustahik, terdiri dari delapan golongan sebagaimana ditegaskan dalam QS. At-Taubah (9): 60. Adapun dalam waktu tertentu berarti ketentuan mengeluarkan zakat sangat terkait dengan waktu, yaitu zakat yang harus dikeluarkan ketika sudah berlalu setahun (haul) bagi objek wajib zakat yang mensyaratkan haul. ${ }^{21}$ Nawawi mengutip pendapat Wahidi menyatakan bahwa jumlah tertentu yang dikeluarkan dari kekayaan itu disebut zakat karena yang dikeluarkan itu menambah banyak, membuat lebih berarti, dan melindungi kekayaan itu dari kebinasaan. ${ }^{22}$ Ibnu Taimiyah menjelaskan bahwa dengan zakat, maka pembayar zakat atau muzakki secara pribadi akan menjadi lebih baik dan kekayaan yang dimilikinya menjadi bersih dan suci. Zakat bersifat menumbuhkan dan membersihkan sang pembayar, tidak terbatas pada harta yang dizakati saja. Demikian pula bagi penerima atau mustahiq, zakat akan menumbuhkan harta dan membersihkan jiwa mereka. ${ }^{23}$

Berdasarkan pengertian-pengertian yang diuraikan di atas dapat ditarik benang merah bahwa zakat merupakan kewajiban seorang Muslim untuk mengeluarkan sebagian hartanya yang telah mencapai nishab (batas minimal) dalam waktu tertetentu dan diberikan kepada orang-orang yang berhak menerima zakat untuk menyucikan dan membersihkan jiwa dan hartanya sesuai dengan yang disyaratkan dalam al-Qur'an. ${ }^{24}$

Karena nilainya yang sangat penting di dalam Islam, zakat sangat ditekankan dalam al-Qur'an. ${ }^{25}$ Bahkan ia merupakan salah satu elemen terpenting dari rukun Islam yang lima. Hal ini berimplikasi pada kafirnya seseorang yang menolak membayar zakat sementara ia mengingkari kewajibannya. Bagi yang menolak membayarnya karena kikir namun masih meyakini kewajibannyanya, maka secara syar'i ia berdosa dan zakat ditarik darinya dengan jalan paksa bahkan ia bisa

${ }^{21}$ Agus Siswanto, dkk, Op. Cit., hal. 329.

${ }^{22}$ Nurul Huda, dkk, Zakat Perspektif Mikro-Makro Pendekatan Riset, (Jakarta: Kencana, 2015), hal. 3.

23 Departemen Ekonomi dan Keuangan Syariah Bank Indonesia dan P3EI Fakultas Ekonomi Universitas Islam Indonesia, Loc. Cit.

${ }^{24}$ Nurul Huda, dkk, Op. Cit., hal. 5.

${ }^{25}$ Sayyid Sabiq, Loc. Cit. 
dikenakan sanksi disiplin. Sementara bagi pihak yang mengumumkan perang karena menolak membayar zakat, maka ia diperangi hingga tunduk pada aturan syara' yang telah digariskan. ${ }^{26}$

Dalam al-Qur'an, zakat sebagai ibadah yang bermuatan sosial ekonomi seringkali disandingkan dengan shalat yang bermuatan ritual. Sabiq ${ }^{27}$ menyebutkan bahwa ada 82 ayat yang menyandingkan kata zakat dengan kata shalat, baik perintah tersebut menggunakan lafal shadaqah maupun zakat. Dari sekian ayat tersebut di antaranya adalah ayat-ayat makkiyyah, yakni ayat-ayat yang diturunkah sebelum peristiwa hijrah. Hal ini juga diperkuat dengan fakta bahwa Islam sejak awal kemunculannya sangat konsen terhadap penanggulangan problem kemiskinan serta orang-orang miskin itu sendiri. ${ }^{28}$ Apabila shalat ditempatkan pada konteks hubungan manusia dengan Allah swt. (hablum minallah), maka zakat diposisikan pada hubungan antar sesama manusia (bablum minannas). Dengan demikian, shalat merupakan ibadah ritual yang memiliki dimensi sosial yang dinyatakan sebagai hikmahnya, sedangkan zakat merupakan ibadah sosial yang berdimensi ritual ('ibadab maliyyah ijtima'iyyah). ${ }^{29}$

Kewajiban zakat yang langsung bersumber dari nash al-Qur'an tidak berarti bahwa posisinya sejajar dan searah dengan posisi shalat yang sering disandingkan dengan kewajiban zakat. Keduanya ibarat saudara kandung yang merupakan pilar ke atas dan ke samping. Pilar ke atas direpresentasikan oleh shalat, yang juga termasuk di dalamnya puasa dan haji, yang pelaksanaannya bersifat individu, yaitu hubungan seorang manusia dengan Tuhannya. Pilar ke samping direpresentasikan oleh zakat yang mencakup hibah, wakaf, hadiah, shadaqah, dan berbagai bentuk hubungan timbal balik berupa praktik transaksi mu'awadhah, seperti jual beli, sewa-menyewa, gadai, dan sebagainya. Uraian ini menegaskan bahwa transaksi mu'awadhah sebetulnya juga mengandung nilai ibadah dengan adanya perintah dan larangan asy-Syari' dalam pelaksanaannya. $^{30}$

Di antara ayat yang menyandingkan kata zakat dan shalat adalah QS alBayyinah (98): 5, yang menyebutkan bahwa

${ }^{26}$ Abu Bakr Jabir al-Jazairi, Op. Cit., hal. 396; Abdullah ad-Dumaiji, Loc. Cit.

${ }^{27}$ Sayyid Sabiq, Loc.Cit.

${ }^{28}$ Ahmad Atabik, "Peranan Zakat dalam Pengentasan Kemiskinan," dalam ZISW AF: Jurnal Zakat dan Wakaf, Vol. 2, No. 2, Desember 2015, (Kudus: IAI Kudus, 2014), hal. 346.

${ }^{29}$ A. Muhyiddin Khotib, Op. Cit., hal. 1-2.

${ }^{30}$ A. Muhyiddin Khotib, Ibid., hal. 3-4. 


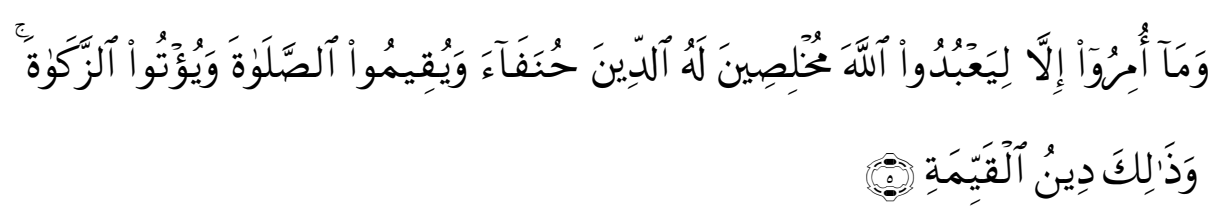

"Padahal mereka tidak disuruh kecuali supaya menyembah Allah dengan memurnikan ketaatan kepada-Nya dalam (menjalankan) agama yang lurus dan supaya mereka mendirikan shalat dan menunaikan zakat; dan yang demikian itulah agama yang lurus.” (QS al-Bayyinah (98): 5).

Menyangkut ayat di atas Imam Syafi'i ${ }^{31}$ menerangkan bahwa Allah mewajibkan kepada orang-orang yang beriman agar mereka menyembah Allah semata dengan memurnikan ketaatan kepada-Nya dalam menjalankan agama, mendirikan shalat, dan menunaikan zakat.

Sementara menurut Ibnu Katsir penyebutan zakat dan shalat secara bersamaan dalam banyak ayat adalah karena keduanya merupakan dua bentuk ibadah vital dalam Islam yang memiliki aspek berbeda. Shalat merupakan bentuk ibadah yang merupakan hak Allah swt. yang terkandung di dalamnya pengesaan, pujian, pengagungan, permohonan, doa, dan penyerahan diri (twakkal) kepada Allah swt. Sementara itu, zakat merupakan hak makhluk (penerima zakat) yang merupakan salah satu bentuk ihsan (perbuatan baik) kepada makhluk. Hal senada juga dijelaskan oleh as-Sa'di yang menyatakan bahwa penyebutan shalat dan zakat secara bersamaan disebabkan shalat mengandung bentuk al-ikblash (keikhlasan) kepada Allah Dzat yang disembah (al-ma'bud). Sedangkan zakat mengandung bentuk al-ibsan (perbuatan baik) kepada hamba Allah swt. ('abdullah). Al-ikhlash dan al-ibsan inilah yang menjadi indikator utama seseorang beruntung atau celaka. ${ }^{32}$

\section{Fungsi dan Tujuan Strategis Zakat}

Zakat mempunyai beberapa dimensi yang sangat luas yaitu meliputi dimensi agamis, moral-spritual, finansial, ekonomi, dan sosial politik yang pada akhirnya adalah untuk mencapai kemakmuran dan kesejehteraan masyarakat. Dari beberapa

${ }^{31}$ Imam asy-Syafi'i, Al-Umm Kitab Induk Fiqih Islam Jilid 3, Terj. Fuad Syaifudin Nur, (Jakarta: Republika Penerbit, 2017), hal. 1-2.

32 Abdul Wahid al-Faizin dan Nashr Akbar, Op. Cit., hal. 102-103. 
tujuan tersebut pada dasarnya mengerucut pada dua aspek pokok, yaitu aspek kebaktian atau ibadah kepada Allah dan amal shalih kepada masyarakat. ${ }^{33}$

Dalam dimensi sosial, zakat merupakan kewajiban sosial yang bersifat ibadah. Hal ini karena zakat yang dikenakan terhadap harta individu ditujukan kepada masyarakat agar terpenuhi kebutuhan dasar mustabik sekaligus bertujuan mengentaskan kemiskinan. Pada dimensi moral, zakat mengikis keserakahan dan ketamakan orang kaya. Sementara dalam dimensi ekonomi, zakat berpotensi mencegah penumpukan harta kekayaan pada segelintir orang tertentu ${ }^{34}$ sebagaimana yang diamanatkan QS. al-Hasyr (59): 7,

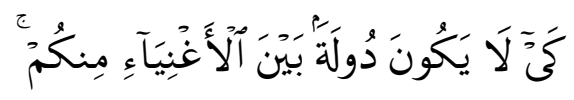

“... Supaya harta itu jangan beredar di antara orang-orang kaya saja di antara kamu...” (QS. al-Hasyr (59): 7)

Ayat di atas, secara faktual memerintahkan setiap orang agar berlaku adil apabila mendapatkan harta. Dalam konteks ini, Islam tidak menghendaki terjadinya penumpukan harta pada sekelompok orang tertentu. Dengan kata lain, harta yang hanya berputar di antara orang-orang kaya perlu dihindari atau setidaknya diminimalisir. Jika tidak, akan ada sekelompok orang yang terlalu kaya, sementara kelompok lainnya terlalu miskin. ${ }^{35}$ Sehingga jika zakat dijalankan sesuai dengan perintah Syari', maka hal itu dapat memupus kerakusan dan ketamakan orang-orang kaya dan pada saat bersamaan orang-orang miskin tidak kehilangan harapan. ${ }^{36}$

Di samping itu, berdasarkan sudut pandang sistem ekonomi pasar, tujuan utama zakat adalah untuk menciptakan distribusi pendapatan menjadi lebih merata. ${ }^{37}$ Dengan adanya zakat, baik itu zakat fitrah maupun zakat maal, diharapkan dapat

33 Moh. Thoriquddin, Pengelolaan Zakat Produktif Perspektif Maqasid al-Syari'ah Ibnu 'Asyur, (Malang: UIN-Maliki Press, 2015), hal. 3. Lihat juga uraian Ahmad Atabik, Op. Cit., hal. 344-345. Bahasan mengenai hikmah zakat dapat dirujuk di antara dalam Heri Sudarsono, Op. Cit., hal. 236-237.

34 Naerul Edwin Kiky Aprianto, "Kontruksi Sistem Jaminan Sosial dalam Perspektif Ekonomi Islam," dalam Economica: Jurnal Ekonomi Islam, Volume 8, Nomor 2, (Semarang: FEBI UIN Walisongo, 2017), hal. 251.

35 Nurul Huda, dkk, Op. Cit., hal. 109-110.

128.

${ }^{36}$ Abdullah Zaky al-Kaaf, Ekonomi dalam Perspektif Islam, (Bandung: Pustaka Setia, 2002), hal. hal. 207.

\footnotetext{
${ }^{37}$ Mustafa Edwin Nasution, dkk, Pengenalan Ekslusif Ekonomi Islam, (Jakarta: Kencana, 2007),
} 
menekan tingkat ketimpangan kekayaan ${ }^{38}$ dan pendapatan antara orang-orang kaya dan orang-orang miskin. Dalam hal perannya sebagai salah satu instrumen distribusi dalam Islam, maka implementasi zakat sewajarnya memperhatikan beberapa prinsip, yakni: 1) pemenuhan kebutuhan bagi semua makhluk; 2) menimbulkan efek positif bagi pemberi itu sendiri, misalnya zakat, selain dapat membersihkan diri dan harta mu₹akki juga diharapkan dapat meningkatkan keimanan dan menumbuhkan kebiasaan berbagi dengan orang lain; 3) menciptakan kebaikan di antara semua orang, baik yang kaya maupun miskin; 4) mengurangi kesenjangan pendapatan dan kekayaan; 5) pemanfaatan lebih baik terhadap sumber daya alam dan aset tetap; dan 6) memberikan harapan pada orang lain melalui pemberian. ${ }^{39}$

Secara spesifik, aplikasi dan implementasi zakat memiliki efek domino, mulai dari sektor produksi, investasi, lapangan kerja, pertumbuhan ekonomi, hingga dampaknya pada minimalisir kesenjangan sosial yang terjadi di tengah-tengah masyarakat.

Dari sisi produksi, zakat akan menimbulkan new demander potensial sehingga zakat dapat meningkatkan permintaan secara agregat yang pada akhirnya akan mendorong produsen untuk meningkatkan kapasitas produksi untuk memenuhi permintaan yang ada. Dampak lain yang dimunculkan dari peningkatan produksi, yakni akan mendorong perusahaan (firms) untuk meningkatkan investasi.

Ada pun dengan adanya peningkatan investasi yang merupakan efek domino berikut dari implementasi zakat adalah mendorong perluasan produksi untuk skala yang lebih besar lagi yang bisa membuka kesempatan kerja. Berikutnya, dikarenakan adanya peningkatan konsumsi secara agregat dan juga peningkatan investasi, maka akan mendorong laju pertumbuhan ekonomi.

Zakat juga berperan dalam mendistribusikan pendapatan, khususnya dalam mengurangi kesenjangan sosial atau gap pendapatan yang pada akhirnya akan meminimalisir kesenjangan sosial. ${ }^{40}$

38 Yoghi Citra Pratama, "Peran Zakat dalam Penanggulangan Kemiskinan (Studi Kasus Program Zakat Produktif pada Badan Amil Zakat Nasional)," dalam The Journal of Taubidinomics, Vol. 1, No. 1, (Jakarta: UIN Syarif Hidayatullah, 2015), hal. 94.

${ }^{39}$ Euis Amalia, Keadilan Distributif dalam Ekonomi Islam Penguatan Peran LKM dan UKM di Indonesia, (Jakarta: Rajawali Pers, 2009), hal. 118-119.

${ }^{40}$ Ika Yunita Fauzia dan Abdul Kadir Riyadi, Prinsip Dasar Ekonomi Islam Perspektif Maqashid al-Syari'ah, (Jakarta: Kencana, 2014), hal. 146-147. 
Sementara Mohammad Daud Ali seperti dikutip Nurul Huda, dkk ${ }^{41}$ mengidentifikasi 9 (sembilan) tujuan zakat yaitu: (1) mengangkat derajat fakir miskin; (2) membantu memecahkan masalah para gharim, ibnu sabil, dan mustahik lainnya; (3) membentangkan dan membina tali persaudaraan sesama umat Islam dan manusia pada umumnya; (4) menghilangkan sifat kikir dan loba para pemilik harta; (5) menghilangkan sifat dengki dan iri (kecemburuan sosial) dari hati orang-orang miskin; (6) menjembatani jurang antara si kaya dan si miskin di dalam pergaulan masyarakat sehari-hari; (7) mengembangkan rasa tanggungjawab sosial pada diri seseorang terutama yang memiliki harta; (8) mendidik manusia untuk berdisiplin menunaikan kewajiban dan menyerahkan hak orang lain padanya; dan (9) sarana pemerataan pendapatan untuk mencapai keadilan.

Di tempat lain Wahbah az-Zuhaily menyatakan bahwa tujuan zakat dari sudut pandang pembangunan kesejahteraan masyarakat memiliki tujuan yang sangat mulia, yakni:

1. Menggalang jiwa dan semangat saling menunjang serta memupuk solidaritas sosial di kalangan masyarakat Islam.

2. Merapatkan dan mendekatkan jarak dan kesenjangan sosial ekonomi dalam masyarakat.

3. Menanggulangi pembiayaan yang mungkin timbul akibat berbagai bencana seperti bencana alam maupun bencana lainnya.

4. Menutup biaya-biaya yang timbul akibat terjadinya konflik, persengketaan dan berbagai bentuk kekerasan dalam masyarakat.

5. Menyediakan dana taktis dan khusus guna penanggulangan biaya hidup para gelandangan, para pengangguran dan para tunasosial lainnya, termasuk dana untuk membantu orang-orang yang hendak menikah akan tetapi tidak memiliki dana untuk itu.

Adapun Yusuf Qardhawi mengutip pendapat al-Kasani menyatakan bahwa zakat memiliki beberapa tujuan dan arti penting yang signifikan, yakni pertama menunaikan zakat merupakan upaya untuk membantu kaum lemah, orang yang membutuhkan pertolongan serta menopang mereka yang lemah agar mampu

\footnotetext{
${ }^{41}$ Nurul Huda, dkk, Op. Cit., hal. 10.
} 
melaksanakan apa yang diwajibkan Allah pada mereka seperti ibadah dan sarana penunjangnya. Dalam konteks ini, menyiapkan sarana untuk melaksanakan kewajiban juga merupakan suatu kewajiban. Kedua, membayar zakat dapat membersihkan diri pelaku dari berbagai dosa dan menghaluskan budi pekertinya sehingga menjadi orang yang pemurah. Realita menunjukkan bahwa pada umumnya manusia cenderung kikir. Ketiga, Allah telah melimpahkan rahmat dan karunia-Nya kepada kaum berada dengan memberikan harta yang melebihi kebutuhan pokok. Dengan demikian, mereka hidup senang di dunia. Sementara itu, mensyukuri nikmat merupakan kewajiban, baik secara akal (aqli) maupun hukum Allah (syar'i). dengan demikian, ada tiga hak yang terkandung dalam kewajiban zakat, yaitu hak fakir miskin, hak masyarakat, dan hak Allah. Dengan kata lain ada kewajiban dalam harta orang-orang mampu yang mesti ditunaikan untuk memenuhi hak-hak pihak lainnya. ${ }^{42}$

Narasi tentang tujuan zakat seperti diuraikan di atas semakin meneguhkan posisi strategis zakat sebagai bentuk nyata solidaritas sosial dalam Islam. Dengan zakat dapat ditumbuhkan rasa kebersamaan dan tanggungjawab untuk saling menolong di antara anggota masyarakat, sekaligus menghilangkan sifat egois dan individualistik. Secara historis, zakat telah direalisasikan secara nyata dan sukses dalam sejarah Islam, bahkan pernah tidak ditemukan lagi orang-orang fakir yang berhak menerima zakat. Yahya bin Said, seorang petugas amil zakat pada masa Umar bin Abdul Aziz (122 H.) pernah diutus oleh Khalifah Umar bin Abdul Aziz untuk mengumpulkan zakat orang-orang Afrika. Dalam tugasnya ia berhasil mengumpulkan zakat dari para muzakki, namun ia kesulitan menemukan orang-orang fakir yang berhak menerima zakat di negeri tersebut. ${ }^{43}$

Dari sudut pandang investasi, zakat memiliki dampak positif guna meningkatkan ketersediaan dana bagi investasi. Hal ini karena pembayaran zakat pada kekayaan dan harta yang tersimpan akan mendorong para wajib zakat untuk mencari pendapatan dari kekayaan mereka sendiri, sehingga mampu membayar zakat dengan tanpa menggerus kekayaan. Dengan demikian, dalam sebuah masyarakat yang nilai-

42 Ahmad Mustahal dan Abdullah Kelib, "Study tentang Pemungutan Zakat Penghasilan Pegawai pada Unit Pengumpul Zakat Kantor Kementerian Agama Kota Salatiga," dalam Jurnal Hukum Khaira Ummah, Vo. 12 No. 1, Maret 2017," (Semarang: Program Master Ilmu Hukum Fakultas Hukum UNISSULA, 2017), hal. 32-33.

${ }^{43}$ Nurul Huda, dkk, Ibid., hal. 11-12. 
nilai islamnya telah terinternalisasi dengan baik, simpanan emas, perak dan kekayaan bentuk lainnya yang tidak produktif cenderung akan berkurang, sehingga pada gilirannya akan meningkatkan jumlah investasi sebagai basis meningkatkan kemakmuran yang lebih luas bagi publik. ${ }^{44}$

Sementara itu, menarik untuk mencatat pendapat ad-Dumaiji ${ }^{45}$ yang menyatakan bahwa kewajiban zakat tidak bersifat personal atau 'ain, di mana pelaksanaannya diserahkan pada kehendak bebas individu, melainkan ia merupakan kewajiban yang bersifat kolektif di mana pengaturan dan pelaksanaannya berada di tangan imam dan para bawahannya. Merekalah yang bertugas memungut zakat dari para wajib zakat dan mengalokasikannya kepada golongan-golongan yang berhak menerima. Dalam tataran ini, pelaksanaan zakat harus diawasi secara langsung oleh penguasa atau imam, dilakukan oleh petugas yang rapi, terstruktur, dan teratur, dipungut dari orang-orang yang wajib mengeluarkannya untuk kemudian diberikan kepada orang-orang yang berhak menerima. Allah telah menyebutkan orang-orang yang bertugas dalam urusan zakat ini, baik petugas pengumpul maupun petugas pembagi zakat. Mereka harus diberi bagian dari harta zakat, agar tanggung jawab dan kewajibannya dapat dijalankan secara maksimal. ${ }^{46}$

\section{Dinamika Teoritis-Praktis Zakat Mal}

Secara praktis, di kalangan sahabat, terutama pasca meninggalnya Nabi Muhammad saw., kebijakan pengelolaan hingga penetapan harta yang wajib dizakati tidak kurang dinamisnya. Umar bin Khaththab, misalnya memungut zakat atas kuda, sesuatu yang tidak pernah dilakukan oleh pendahulunya, baik oleh Nabi Muhammad saw., maupun Abu Bakar. Pada awalnya memang Umar tampak ragu atas kebijakan ini. Namun seperti ditegaskan Qardhawi, ${ }^{47}$ setelah terlebih dahulu mengumpulkan data-data terkait, bermusyawarah dengan beberapa sahabat senior, menganalisis,

44 Junaidi Safitri, "Implementasi Konsep Zakat dalam Al-Qur'an Sebagai Upaya Mengentaskan Kemiskinan di Indonesia," dalam MUKADDIMAH: Jurnal Studi Islam, Volume 2 No. 1, Juni 2017, (Yogyakarta: Kopertais Wilayah III Yogyakarta, 2017), hal. 23.

45 Abdullah ad-Fumaiji, Loc. Cit.

46 Ahmad Syafiq, "Prospek Zakat dalam Perekonomian Modern," dalam ZISWAF: Jurnal Zakat dan Wakaf, Vol. 1, No. 1, Juni 2014, (Kudus: IAI Kudus, 2014), hal. 150.

${ }^{47}$ Yusuf Qardhawi, Membumikan Syariat Islam Keluwesan Aturan Ilabi untuk Manusia, Terj. Ade Nurdin dan Riswan, (Bandung: Arasy, 2003), hal. 235. 
hingga akhirnya ia menarik satu istimbath hukum bahwa setiap satu ekor kuda, baik betina atau jantan dikenakan zakat sejumlah satu dinar. Di sini, Umar mengubah fatwanya tentang zakat kuda disebabkan terjadinya perubahan situasi kondisi. Ia tidak terpaku pada pendapat pertama karena ijtihad selalu berubah mengikuti perubahan kondisi.

Contoh yang lain adalah pandangan Umar bin Khaththab mengenai penangguhan pemberian porsi zakat bagi golongan yang dikenal pada masa Nabi saw., dan Khalifah Abu Bakar sebagai al-mu'allafah qulububum (orang yang dibujuk hatinya). Terkait dengan ini, ia berujar "Sesungguhnya Allah telah memuliakan Islam, dan tidak lagi memerlukan mereka."

Dengan kebijakan tersebut, tidak berarti menggugurkan hukum al-Qur'an dan as-Sunnah, juga bukan menghapuskan saham zakat kelompok ini untuk selamanya sebagaimana dipahami oleh sebagian ulama'. Sebenarnya jatah mereka tetap ada, tidak hilang karena hukum tidak bisa dihapus setelah wahyu berhenti. Suatu hal yang mustahil terjadi bila Umar dan para sahabat lainnya berani menggugurkan sesuatu yang telah ada dalam al-Qur'an dan as-Sunnah.

Semua yang dilakukan oleh Umar disebabkan oleh pandangannya bahwa pada masa itu, Islam tidak lagi memerlukan mu'allaf. Ia melarang setiap orang terus menerus mengambil zakat atas nama ta'lif (menjinakkan hati orang yang baru masuk Islam). Penetapan mengenai perlu tidaknya ta'lif dan penentuan siapa atau golongan mana yang masih dianggap perlu, merupakan wewenang imam atau penguasa berdasarkan hasil musyawarah dengan orang-orang yang dianggap kredibel. ${ }^{48}$ Bahkan lebih dari itu, Umar, Amir, dan Sya'bi berpendapat bahwa mu'allaf tidak boleh diberi zakat sepeninggal Nabi saw., karena Allah telah memuliakan Islam dan pemeluknya. Hanya saja jika faktor-faktor yang mengharuskan pembujukan hati terulang, maka zakat dapat diberikan kembali kepada mu'allaf. ${ }^{49}$

Di tempat lain, Karim $^{50}$ mencatat kebijakan serupa dari Umar, di mana ia mengenakan khums zakat atas karet yang ditemukan di semenanjung Yaman, antara

48 Yusuf Qardhawi, Ibid., hal. 236.

${ }^{49}$ Muhammad Nasib ar-Rifa'i, Ringkasan Tafsir Ibnu Katsir Jilid 2, Terj.Syihabuddin, (Jakarta: Gema Insani, 2012), hal. 440-441. Lihat juga Holilur Rohman, Maqasid al-Syariah, (Malang: Setara Press, 2019), hal. 46-47.

${ }^{50}$ Adiwarman Azwar Karim, Op. Cit., hal. 69-70. 
Aden dan Mukha, dan hasil laut karena barang-barang tersebut dianggap sebagai hadiah dari Allah. Tidak hanya itu, Umar juga menetapkan zakat madu atas penduduk Thaif sebagaimana yang telah dilakukan Nabi Muhammad saw. Hanya saja ia mengelompokkan madu tersebut menjadi dua bagian yakni madu yang diperoleh dari pegunungan dan madu yang diperoleh dari ladang. Pembagian ini menentukan besaran zakat yang dikenakan. Zakat yang ditetapkan untuk madu jenis pertama adalah seperduapuluh dan sepersepuluh untuk madu jenis kedua.

Sementara itu, Abu Bakar juga membebani zakat terhadap war, sejenis rumput herbal yang digunakan sebagai bahan baku pembuatan bedak dan parfum. ${ }^{51}$

Tidak jauh berbeda dengan kebijakan yang ditetapkan oleh Umar bin Khaththab dan Abu Bakar seperti telah diuraikan di atas, Utsman bin Affan seperti dicatat ash-shallabi ${ }^{52}$ juga menetapkan kebijakan serupa. Di antara kebijakannya adalah: menetapkan zakat atas piutang orang-orang kaya; meminjam uang zakat untuk kemaslahatan umum, terutama untuk membiayai perang dan layanan publik lainnya; memberi makan orang-orang miskin dan ibnu sabil dari uang zakat; membangun beberapa rumah singgah dari uang zakat; dan memberi uang saku bagi para budak.

Sementara di tempat lain, Abu Dzar al-Ghifari memilik pendapat yang bersebrangan dengan pendapat mayoritas sahabat Nabi saw., menyangkut zakat emas dan perak. Jika mayoritas sahabat Nabi saw., berpendapat bahwa tidak ada kewajiban zakat pada emas yang kurang dari lima uqiyah, maka Abu Dzar al-Ghifari berpendapat bahwa emas dan perak berapa pun jumlahnya tidak layak disimpan oleh seorang Muslim, seluruhnya harus diinfakkan. Ia berdalil dengan QS. at-Taubah (9): 34-35. Pada ayat 34 secara substantif dideskripsikan kebiasaan orang-orang Yahudi dan Rahib-Rahib Nasrani dalam hal memakan harta orang lain dengan jalan batil dan menghalang-halangi manusia dari jalan Allah. Pada ayat sama juga dideskripsikan siksa yang teramat pedih bagi orang-orang yang menyimpan atau menimbun emas dan perak secara mutlak dan bersikukuh tidak menginfakkannya.

\footnotetext{
${ }^{51}$ Adiwarman Azwar Karim, Ibid., hal. 69.

52 Urain lengkap tentang kebijakan penggunaan uang zakat pada masa Utsman bin Affan dapat merujuk Ali Muhammada ash-Shallabi, Biografi Utsman bin Affan, Terj. Umarul Faruq Abubakar, (Jakarta Timur: Ummul Qura, 2017), hal. 168-172.
} 
Ada pun ayat 35 merinci bentuk azab di akhirat kelak bagi orang yang menimbun emas dan perak semasa di dunia, yakni dipanaskannya emas dan perak tersebut di neraka Jahannam, lalu dibakar dengannya dahi, lambung, dan punggung mereka. Lalu dikatakan kepada mereka, "Inilah harta bendamu yang kamu simpan untuk dirimu sendiri, maka rasakanlah sekarang (akibat dari) apa yang kamu sekalian simpan. ${ }^{, 53}$

Terlepas dari keberadaan dasar normatif, pendapat Abu Dzar al-Ghifari ini bertentangan dengan pendapat mayoritas sahabat dan generasi setelahnya. Umumnya dipahami bahwa emas yang dipakai sebagai perhiasan kaum hawa dalam batas yang wajar tidak dikenakan zakat. ${ }^{54}$ Berbeda halnya jika dikenakan dalam jumlah yang berlebih-lebihan. Dalam kasus ini, perhiasan tersebut wajib dizakati sebagaimana pendapat beberapa sahabat senior seperti Jabir bin Abdullah, Ibnu Umar, Asma' binti Abu Bakar, dan Aisyah. ${ }^{55}$ Ada pun menyangkut maksud emas dan perak yang ditimbun (yaknizuna adz-dzahaba wa al-fiddhah) seperti tertera dalam QS. at-Taubah (9): 34, Ibnu Umar menyatakan bahwa yang dimaksud adalah harta yang tidak dikeluarkan zakatnya. ${ }^{56}$

Fakta lain yang penting dicatat adalah Umar bin Abdul Aziz pada masa pemerintahannya juga pernah menetapkan zakat atas gaji, honorarium, dan juga hadiah yang diterima seseorang. ${ }^{57}$

Di tempat lain, Abu Hanifah, yang dikenal sebagai tokoh abl al-ra'yi yang dalam setiap produk hukumnya seringkali mengedepankan maqashid syariah membolehkan berzakat dengan uang senilai seekor kambing sebagai pengganti dari kambing itu sendiri. Hal ini karena tujuan zakat adalah untuk memenuhi kebutuhan orang miskin, di mana hal itu dapat direalisasikan dengan berzakat kambing atau dengan uang senilai kambing itu. ${ }^{58}$

\footnotetext{
${ }^{53}$ Uraian selengkapnya mengenai dialektika Abu Dzar al-Ghifari dengan beberapa sahabat senior menyangkut menyimpan emas dan perak dapat ditelusuri dalam Ali Muhammada ash-Shallabi, Ibid., hal. 389-398. Lihat juga Khalid Muhammad Khalid, Biografi 60 Sababat Nabi, Terj. Agus Suwandi, (Jakarta Timur: Ummul Qura, 2018), hal. 63-87; Abdullah Zaky al-Kaaf, Op. Cit., hal. 151-161. 2017), hal. 64.

${ }^{54}$ Imam adz-Dzahabi, Dosa-Dosa Besar, Terj. Umar Mujtahid, (Jakarta Timur: Ummul Qura,

55 Oni Sahroni, Fikih Muamalah Kontemporer Jilid 4, Jakarta: Republika Penerbit, 2020, hal. ) $54-55$

${ }^{56}$ Muhammad Nasib ar-Rifa'i, Op. Cit., hal. 422.

${ }^{57}$ Ahmad Mustahal dan Abdullah Kelib, Op. Cit., hal. 31.

${ }^{58}$ Holilur Rohman, Op. Cit., hal. 145.
} 
Sementara itu, Ibnu Hazm dalam kapasitasnya sebagai tokoh utama mazhab zhahiri memperluas jangkauan harta yang wajib dizakati. Ia menegaskan bahwa ada kewajiban sosial di luar zakat yang harus dipenuhi oleh orang kaya. Ini merupakan bentuk kepedulian dan tanggung jawab sosial mereka kepada orang miskin, anak yatim, dan orang-orang yang lemah secara ekonomi. Bahkan jika ternyata zakat dan harta kaum Muslimin (Baitul Mal) tidak dapat memenuhi kebutuhan primer kaum papa, maka pemerintah atau negara dibolehkan memaksa orang-orang kaya mengeluarkan hartanya selain zakat. ${ }^{59}$

Belakangan, Yusuf Qardhawi seperti dicatat al-Kaaf ${ }^{60}$ berpendapat bahwa seiring perkembangan dan kemajuan perekonomian yang sangat pesat, tidak menutup kemungkinan timbul objek wajib zakat baru selain yang telah dipaparkan ulama' terdahulu. Ia menyebutkan beberapa jenis objek wajib zakat baru seperti zakat madu lebah dan segala produk pembibitan hewan, zakat penghasilan barang-barang tambang dan penghasilan laut, zakat atas hasil usaha, baik berupa bangunan, pabrik, industri dan sejenisnya, hingga zakat terhadap saham dan sejenisnya.

\section{Zakat Mal: Antara Ibadah Mahdhah dan Mu'amalah Maliyyah}

Di atas sekilas telah diuraikan posisi zakat yang terhimpit antara ibadah yang benuansa ritual dengan mu'amalah maliyyah ijtima'yyah yang mengandung aspek sosial ekonomi. Dijelaskan pula bahwa dari aspek teoritis-praktis zakat ternyata sangat dinamis, bahkan pada masa generasi awal Islam.

Perlu ditegaskan kembali bahwa sebagai sebuah ibadah, zakat bersifat wajib bagi setiap Muslim yang telah memenuhi syarat pada harta yang dimilikinya. Pada sisi ini, nuansa ritual sangat kental. Ada rukun dan syarat tertentu yang harus dipenuhi laiknya ibadah mahdhah lainnya semisal shalat, haji dan puasa ramadhan. Sehingga kemanfaan zakat dirasakan secara individu oleh pihak muzakki seperti perasaan bebas dari kewajiban. Dengan begitu, zakat jika ditunaikan dengan baik sesuai dengan perintah syariat, maka dapat meningkatkan kualitas keimanan, membersihkan dan menyucikan jiwa, sekaligus mengembangkan dan menambah

${ }^{59}$ Euis Amalia, Op. Cit., hal. 128.

${ }^{60}$ Uraian selengkapnya bisa dilihat di Abdullah Zaky al-Kaaf, Op. Cit., hal. 130-131. 
keberkahan harta benda yang dimiliki. ${ }^{61}$ Itu sebabnya, dalam kedudukannya sebagai ibadah zakat diposisikan sebagai salah satu pilar (rukun) dalam Islam sebagaimana ditegaskan oleh Rasulullah SAW., dalam sebuah hadits yang diriwayatkan oleh Abdullah bin Umar bahwa,

"Islam dibangun di atas lima tonggak: syahadat la ilaha illallah dan Muhammad adalah utusan Allah, menegakkan shalat, membayar zakat, haji ke baitullah, dan puasa pada bulan ramadhan.” (HR. al-Bukhari)

Sementara pada sisi yang lain, zakat merupakan filantropi yang bersifat obligatori, di mana kemanfaatan zakat dirasakan secara kolektif oleh orang-orang yang berada di lingkungan yang menjalankan sistem zakat. Dalam konteks ini fungsi zakat tidak dapat dilepaskan dari posisi strategisnya sebagai salah satu bentuk interaksi sosial antara pemberi zakat (muzakki) dan penerima zakat (mustabik). ${ }^{62}$ Bahkan lebih dari itu, zakat merupakan manifestasi kegotongroyongan antara orang kaya di satu sisi dan fakir miskin pada sisi lainnya. Pemberdayaan zakat merupakan perlindungan sosial bagi masyarakat dari bencana ekonomi yakni kemiskinan dan juga kelangkaan suatu komoditas. Sedangkan lembaga zakat pada dimensi lain merupakan sarana dan alat distribusi kekayaan yang paling otoritatif, memiliki kewajiban kolektifikasi terhadap perekonomian umat Islam secara umum. Di sini konsep zakat punya hitung-hitungan sendiri dalam penyucian dan pembersihan harta, terutama agar yang kaya tidak merasa terbebani melebihi kapasitas dirinya dan yang miskin dapat mengakses sumber modal secara berkesinambungan. Dalam ekonomi Islam hal ini merupakan instrumen pengentasan kemiskinan dalam bentuk distribusi pendapatan atau bahkan kekayaan. ${ }^{63}$

Dari sudut pandang sosiologis, dana zakat yang dihimpun akan sangat membantu orang yang berhak menerimanya (mustabik). Zakat akan memperkecil kesenjangan sosial, meminimalisir jurang pemisah antara si kaya dan si miskin. Implementasi zakat juga berpotensi menumbuhkan nilai-nilai persaudaraan dan

61 Siti Nurhasanah dan Suryani, "Maksimalisasi Potensi Zakat Melalui Peningkatan Kesadaran Masyarakat" dalam JEBI (Jurnal Ekonomi dan Bisnis Islam), Volume 3, Nomor 2 JuliDesember 2018, (Padang: FEBI UIN Imam Bonjol Padang, 2018), hal. 186.

${ }^{62}$ Abdul Wahid al-Faizin dan Nashr Akbar, Op. Cit., hal 101-102.

${ }^{63}$ Junaidi Safitri, Op. Cit., hal. 21-22. 
kekeluargaan. Sementara itu, tujuan mendasar zakat adalah untuk menyelesaikan berbagai macam persoalan sosial seperti kemiskinan, pengangguran, dan penyakit sosial lainnya. Sistem distribusi zakat merupakan solusi terhadap persoalan-persoalan tersebut dan memberikan bantuan kepada orang-orang miskin tanpa memandang strata sosial, ras, warna kulit, etnis, dan atribut-atribut keduniawian lainnya. ${ }^{64}$

Perlu ditegaskan bahwa dalam penetapan kewajiban zakat, barang yang wajib dizakati, kadar zakat, dan golongan yang berhak mendapatkan zakat, diperoleh dari dalil al-Qur'an dan as-Sunnah. Di dalam al-Qur'an terdapat banyak ayat yang menjelaskan tentang kewajiban zakat, baik berbentuk kata yang tersusun dari akar kata زكاة atau yang berbentuk kata نفاق . Setidaknya terdapat 30 ayat yang menerangkan zakat yang tersusun dari akar kata زكاة

Bentuk-bentuk ayat di dalam al-Qur'an yang menerangkan zakat beraneka ragam. Dalam hal ini dapat dikelompokkan ke dalam tiga kategori, yakni amr atau perintah, pujian, dan ancaman.

Salah satu ayat yang menjelaskan kewajiban zakat dalam bentuk amr adalah QS. Al-Baqarah (2): 43,

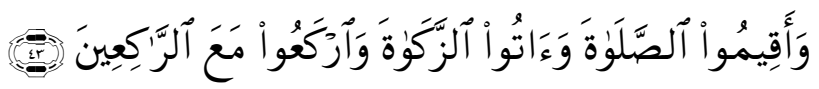

"Dan dirikanlah shalat, tunaikanlah zakat dan rukuklah beserta orang-orang yang rukuk.” (QS. Al-Baqarah (2): 43)

Dalam menafsirkan ayat ini, Ibnu Abidin (w. 1252 H.) menyatakan bahwa yang dimaksudkan dengan kata أتوا adalah melaksanakan dan menyerahkan zakat itu kepada orang yang berhak. Lebih lanjut, beliau menegaskan bahwa perintah menunaikan zakat ini semata sebagai bentuk syukur atas nikmat yang Allah berikan sekaligus sebagai sarana menyambung silaturrahmi antar sesama manusia.

Selain amr, perintah zakat dalam al-Qur'an juga berbentuk pujian atau kabar gembira kepada orang yang menunaikan zakat, misalnya QS. Maryam (19): 55 berikut ini,

64 Firmansyah, "Zakat sebagai Instrumen Pengentasan Kemiskinan dan Kesenjangan Pendapatan," dalam Jurnal Ekonomi dan Pembangunan, Vol. 21, No. 2, Desember 2013, (Jakarta: LIPI, 2013), hal. 180. 


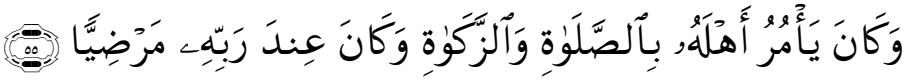

"Dan ia menyuruh keluarganya untuk shalat dan menunaikan zakat, dan ia adalah seorang yang diridhai di sisi Tuhannya." (QS. Maryam (19): 55)

Selain memberikan pujian kepada orang yang menunaikan zakat, Allah juga memberikan ancaman yang pedih kepada orang yang tidak menunaikan zakat. Pernyataan tersebut tercatat dalam QS. Al-Fussilat (41): 6-7,

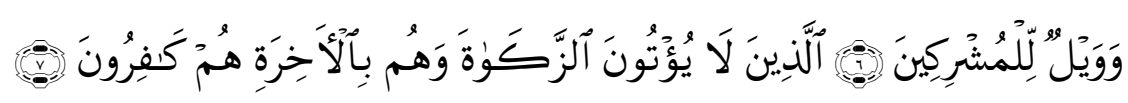

“.... Dan kecelakaan besarlah bagi orang-orang yang mempersekutukanNya. (Yaitu) orang-orang yang tidak menunaikan zakat dan mereka kafir akan adanya (kehidupan) akhirat.” (QS. Al-Fussilat (41): 6-7)

Asbabun nигul ayat di atas seperti dinyatakan Imam Abu Zakaria al-Farra' adalah berkaitan dengan kaum Quraisy yang selalu menjamu makan dan minum orang-orang yang tawaf di Makkah. Namun setelah kedatangan Islam, mereka hanya memberikannya kepada orang-orang yang beragama selain Islam.

Pada ayat di atas, terdapat kemusykilan. Seorang musyrik (orang yang tidak beragama Islam) terkena beban untuk menjalankan syariat zakat. Oleh karenanya, Imam al-Mawardi dalam tafsirnya mengemukakan lima makna, yakni: pertama, pendapat Imam Ibnu Isa, bahwa yang dimaksud dengan orang musyrik yang celaka adalah orang-orang musyrik yang kaya raya dan terkena kewajiban zakat lebih pedih azabnya daripada orang musyrik yang miskin namun tidak mampu berzakat. Kedua, pendapat Ibnu Umar bahwa kalimat la yu'tuna az-zakah yang dimaksudkan bukan tidak menunaikan zakat, melainkan tidak membersihkan dirinya dari perbuatan dosa. Ketiga, pendapat Imam Hasan, bahwa yang dimaksudkan adalah orang-orang musyrik yang kaya disiksa karena kekayaan itu tidak dapat mengantarkan mereka menjadi orang-orang suci. Keempat, pendapat Imam Qatadah, bahwa orang-orang musyrik itu celaka karena mereka mengingkari zakat sebagai syariat Islam. Pengingkaran ini merupakan wujud dari pengingkaran mereka terhadap Islam. Kelima, pendapat Mu'awiyyah bin Qarrah, bahwa yang dimaksud dalam ayat di atas adalah mereka disiksa bukan karena mereka tidak berzakat, melainkan karena mereka melakukan hal-hal tersebut sementara mereka dalam keadaan yang tidak pantas untuk 
melakukannya. Pendapat yang terakhir ini merupakan pendapat yang diunggulkan oleh mayoritas ulama'. ${ }^{65}$

Sementara itu, dalil-dalil al-Qur'an yang menerangkan tentang zakat seluruhnya bersifat umum. QS. al-Baqarah (2): 43 misalnya, yang menjelaskan tentang hukum kewajiban zakat,

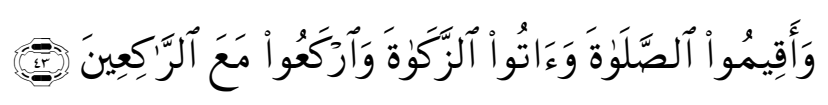

"Dan dirikanlah shalat, tunaikanlah zakat dan rukuklah bersama orangorang yang rukuk.” (QS. al-Baqarah (2): 43)

Demikian pula dengan dalil-dalil yang menjelaskan tentang objek-objek zakat, seperti QS. al-Baqarah (2): 267,

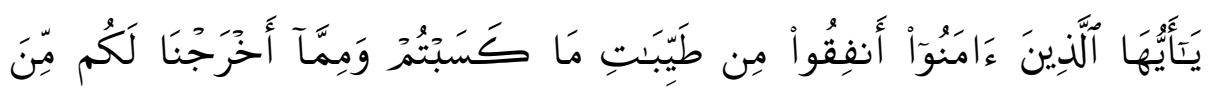

"Hai orang-orang yang beriman, nafkahkanlah" (di jalan Allah) sebagian dari hasil usahamu yang baik-baik dan sebagian dari apa yang telah kami keluarkan dari bumi untuk kamu.’”( QS. al-Baqarah (2): 267)

Kalimat أخرجنا لكم من الارضseperti terdapat dalam QS. al-Baqarah (2): 267 di atas merupakan kalimat yang penunjukannya bersifat zhanni. Sehingga tidak ada kejelasan apa yang dimaksud dengan kata-kata tersebut. ${ }^{67}$ Ia mencakup tanaman apa saja yang ditumbuhkan oleh bumi, baik sedikit atau banyak, termasuk komoditas pangan (makanan pokok) atau selainnya. ${ }^{68}$ Dari sini wajar kemudian jika para ulama' memiliki penafsiran yang berbeda-beda terkait ayat di atas. Penafsiran mereka erat sekali kaitannya dengan kondisi pertanian di daerah mereka masing-masing. Hal ini karena sesuatu yang keluar dari bumi di daerah mereka berbeda-beda sehingga ini

65 A. Muhyiddin Khotib, Op. Cit., hal 72-76.

${ }^{66}$ Penting dicatat pendapat Ibnu Abbas, seorang ahli tafsir di kalangan sahabat seperti dikutip Ibnu Katsir bahwa term anfiqu dalam QS. al-Baqarah (2): 267 mengacu pada shadaqah sunnah buka zakat yang diwajibkan. Dikaitkan dengan ayat tersebut Ibnu Abbas menerangkan bahwa Allah menyuruh mereka menginfakkan harta yang paling baik, paling bagus, dan paling elok dari harta kekayaan yang telah mereka usahakan. Selengkapnya periksa Muhammad Nasib ar-Rifa'i, Ringkasan Tafsir Ibnu Katsir Jilid 1, Terj.Syihabuddin, (Jakarta: Gema Insani, 2012), hal. 336.

${ }^{67}$ A. Muhyiddin Khotib, Op. Cit., hal. 144.

${ }^{68}$ Syauqi Ismail Sahhatih, Op. Cit., hal. 220. 
juga yang menyebabkan perbedaan penafsiran mereka terhadap nash-nash syariat. Menurut Imam asy-Syafi'i apa saja yang dikonsumsi sebagai camilan tidak wajib zakat. Di lain pihak, Imam Malik bin Anas berpendapat bahwa yang wajib dizakati hanya gandum, selainnya tidak wajib dizakati. Berbeda dengan Imam asy-Syafi'i dan Imam Malik, menurut Imam Abu Hanifah bahwa apa saja yang keluar dari bumi, baik berupa biji-bijian atau semacamnya, seluruhnya wajib dikeluarkan zakatnya, kecuali dua komoditas yakni kayu bakar dan bambu. Sedangkan menurut Imam Ahmad bin Hambal, segala sesuatu yang keluar dari bumi, kecuali bambu wajib dikeluarkan zakatnya. ${ }^{69}$ Bahkan semua jenis biji-bijian yang bisa disimpan wajib dikeluarkan zakatnya, meskipun mungkin tidak termasuk makanan pokok. ${ }^{70}$

Selanjutnya, para ulama' berselisih pendapat mengenai status zakat. Menurut Imam asy-Syafi'i, esensi zakat lebih condong pada fungsinya sebagai alat dan faktor pemerataan, sedangkan esensi ibadah dalam zakat hanya sebagai tambahan. Oleh karena itu, zakat merupakan biaya finansial yang harus didapatkan oleh orang-orang miskin dari orang-orang kaya. Dengan begitu, yang menjadi fokus utama dalam zakat adalah pemenuhan kebutuhan orang-orang miskin.

Sedangkan menurut Imam Abu Hanifah, esensi zakat adalah ibadah, sedangkan unsur kesetaraan adalah tambahan. Hal ini berkonsekuensi pada fungsi utama zakat pada fungsi utama zakat sebagai riyadat an-nafs (melatih diri), sehingga yang jadi fokus utama dalam zakat adalah taklif (pembebanan) terhadap kelompok kaya agar bijak mengalokasikan harta bendanya.

Perbedaan pandangan ulama' mengenai apakah zakat merupakan ibadah atau hak yang wajib bagi orang-orang miskin dengan sendirinya akan menimbulkan beberapa konsekuensi. Menurut Ibnu Rushd, salah satu dampak dari perbedaan ini adalah boleh dan tidaknya zakat dikeluarkan sebelum waktunya. Bagi yang mengatakan bahwa zakat adalah ibadah, maka tidak boleh mengeluarkan zakat sebelum waktunya. Sedangkan bagi yang berpendapat bahwa zakat merupakan kewajiban yang bertempo, maka boleh mengeluarkan zakat sebelum waktunya. ${ }^{71}$

\footnotetext{
${ }^{69}$ A. Muhyiddin Khotib, Loc. Cit.

${ }^{70}$ Syauqi Ismail Sahhatih, Loc. Cit.,

71 A. Muhyiddin Khotib, Ibid., hal. 157-158.
} 
Konsekuensi lain dari perbedaan pendapat tersebut adalah menyangkut apakah wajib zakat mensyaratkan baligh dan berakal sebagaimana ibadah mahdhah lainnya ataukah tidak. Bagi yang memposisikan zakat sebagai ibadah seperti Imam Abu Hanifah, maka anak kecil yang belum sampai usia baligh tidak berkewajiban menenunaikan zakat. Hal ini karena di antara syarat sahnya ibadah adalah baligh dan berakal. Sementara bagi jumhur ulama' yang diwakili oleh Imam asy-Syafi' yang memposisikan zakat sebagai alat dan faktor pemerataan, maka baligh dan berakal tidak menjadi syarat wajib zakat. Dengan demikian, setiap orang yang memiliki harta benda yang memenuhi syarat, baik ia telah baligh atau belum, berakal ataukah mengalami gangguan jiwa, maka ia telah berkewajiban mengeluarkan zakat.

Bagi mayoritas ulama', Islam mengharuskan zakat atas harta yang dimiliki anak yatim, orang gila, termasuk juga anak yang belum baligh yang berada dibawah perwalian seseorang. Ini bertujuan agar harta benda tersebut dapat terus dikembangkan dan dikelola oleh sang wali sehingga menjadi motivasi baginya untuk mendapatkan hasil yang melimpah. Oleh karenanya, ajaran zakat merupakan ajaran untuk bekerja, berusaha, sampai pada suatu titik tertentu, yakni adanya suatu hasil yang dibuktikan dengan bertambahnya harta benda. ${ }^{72}$

Ditetapkannya zakat pada harta yang dimiliki oleh orang yang belum sampai derajat taklif seperti orang gila dan anak yang belum baligh sebagaimana yang menjadi pegangan mayoritas ulama' adalah karena zakat adalah hak harta. ${ }^{73}$ Sehingga siapa saja yang memiliki harta yang telah mencapai standar minimal serta mencapai haul, maka harta tersebut wajib dikeluarkan zakatnya. Bahkan di tempat lain, Sahhatih $^{74}$ mengutip kesepakatan Imam Malik, Imam asy-Syafi'i, dan Imam Ahmad, di mana ketiga imam mazhab tersebut menegaskan bahwa kewajiban zakat tidak gugur dengan meninggalnya pemilik harta benda. Zakat wajib dikeluarkan dari harta itu, sekalipun dia tidak mewasiatkannya. Hal ini seperti telah ditegaskan di atas adalah karena zakat merupakan suatu hak yang berkaitan dengan harta.

Masih dalam catatan Sahhatih, fuqaha' Hanafiyah mengaitkan kewajiban membayar zakat orang yang telah meninggal dunia dengan keberadaan wasiat. Jika

\footnotetext{
${ }^{72}$ Ika Yunita Fauzia dan Abdul Kadir Riyadi, Op. Cit., hal. 144-145.

${ }^{73}$ Syauqi Ismail Sahhatih, Op. Cit., hal. 94.

${ }^{74}$ Syauqi Ismail Sahhatih, Ibid., hal. 96.
} 
sebelum meninggal dunia pemilik harta dimaksud berwasiat agar hartanya dizakati, maka zakat itu dikeluarkan dari sepertiga hartanya oleh orang-orang yang menerima wasiat secara kolektif. Namun jika tidak ada wasiat, maka dengan sendirinya kewajiban zakat gugur. Hal ini karena menurut fuqaba' Hanafiyah zakat itu termasuk ibadah, yang mana di antara syaratnya adalah niat. Sementara asas legalitas dari niat adalah al-bulugh dan al'aql. Oleh karena itu, dengan meninggalnya orang yang telah berkewajiban untuk ibadah, maka ibadah itu pun gugur sebagaimana halnya puasa atau puasa ramadhan.

Namun demikian, pendapat fuqaha' Hanafiyah itu disanggah oleh fuqaha' Hambali. Menurut mereka zakat adalah kewajiban yang boleh diwasiatkan dan tidak otomatis gugur dengan meninggalnya seseorang, sebagaimana halnya dengan utang. Terlebih lagi zakat itu merupakan bagian dari harta yang wajib dikeluarkan, tidak gugur dengan meninggalnya orang yang berkewajiban mengeluarkannya seperti halnya utang. Pada titik ini, zakat berbeda dengan ibadah puasa dan shalat, yang mana keduanya merupakan ibadah badaniah yang tidak dapat diwasiatkan atau pun diwakilkan kepada orang lain agar dilaksanakan.

Dari uraian di atas tampak bahwa secara normatif ayat-ayat al-Qur'an yang menerangkan tentang zakat seluruhnya bersifat umum, terutama jika dikaitkan denga objek wajib zakat. Ayat zakat yang dipandang memiliki makna yang khusus hanyalah QS. at-Taubah (9): 60 yang mengurai pihak-pihak yang berhak menerima zakat, yakni orang-orang fakir, orang-orang miskin, amil zakat, mu'allaf yang dibujuk hatinya, untuk keperluan memerdekakan budak, orang-orang yang berutang, untuk kepentingan fi sabilillah, dan untuk orang-orang yang sedang berada di dalam perjalanan.

Kedelapan golongan mustabik zakat tersebut oleh Rasyid Ridha seperti dikutip al-Kaaf ${ }^{75}$ dapat dikelompokkan menjadi dua bagian, yakni pertama, individuindividu yang terdiri dari enam golongan: orang-orang fakir, orang-orang miskin, amil zakat, mu'allaf yang perlu dibujuk hatinya, orang-orang yang berutang (gharim), dan ibnu sabil. Bagian yang kedua adalah untuk kepentingan umum dari masyarakat dan negara yang terdiri dari dua golongan, yakni untuk pembebasan dan kemerdekaan

${ }^{75}$ Abdullah Zaky al-Kaaf, Op. Cit., hal. 129. 
bagi masing-masing diri (individu), golongan, atau bangsa yang disebut fir riqab. Sementara golongan yang kedua adalah untuk segala kepentingan, masyarakat dan negara, yang bersifat pembangunan dalam segala lapangan atau pembelaan perjuangan yang disebut dengan fi sabilillah.

Walau bagaimana pun juga, dengan dimasukkannya zakat dalam pembahasan ibadah, maka zakat kemudian dianggap sebagai bidang yang jauh dari pemikiran (ijtihadi). Sebagai konsekuensinya pembahasan zakat menjadi statis dan tidak menerima diskusi (qabil li al-niqas). Dengan demikian, zakat pada gilirannya menjadi kehilangan sifat vitalnya untuk kemanusiaan, padahal zakat seharusnya dapat memberikan dampak besar bagi kemanusiaan. Sebagai ibadah yang bersifat maliyyah ijtima’iyyah, zakat semestinya dapat mengangkat status seorang Muslim dari fakir miskin menjadi orang yang berekonomi memadai, atau mengacu pada konsep zakat, dari seorang mustabik menjadi muzakki. Oleh karena itu, sudah seyogianya zakat ditempatkan bukan hanya pada bidang ibadah, akan tetapi dimasukkan dalam bidang muamalah. Yusuf Qardhawi termasuk intelektual Muslim yang setuju, bahkan ia menyimpulkan bahwa pembahasan fiqih zakat tidak harus diletakkan dalam pembahasan ibadah, namun semestinya dibahas dalam bidang muamalah. Lebih lanjut, ia menegaskan bahwa zakat adalah sistem keuangan, ekonomi, sosial, politik, moral dan agama sekaligus. Dengan ditempatkannya pembahasan zakat dalam bidang muamalah, maka dengan sendirinya peluang untuk melakukan ijtihad terhadap zakat semakin terbuka lebar. ${ }^{76}$

\section{KESIMPULAN}

Hal yang paling substansial dari zakat adalah posisinya yang berada dalam dua ranah sekaligus, yakni ranah ibadah mahdhah dan mu'amalah maliyah. Sebagai ibadah mahdhah zakat bersifat ta'aabudi, sementara dalam hal posisinya sebagai mu'amalah maliyah ijtima'iyyah ia bersifat ta'aqquli.

Sejauh dapat dilacak, satu-satunya alasan dimasukkannya zakat ke dalam domain ibadah adalah karena Nabi Muhammad saw., sendiri dalam salah satu haditsnya yang diriwayatkan Imam Bukhari dari jalur Abdullah bin Umar telah

\footnotetext{
${ }^{76}$ A. Muhyiddin Khotib, Loc. Cit., hal. 102-103.
} 
memposisikan zakat bersamaan dengan syahadatain, shalat, haji, dan puasa pada bulan ramadhan. Posisi ini menjadikan zakat, terutama dari sisi objeknya bisa dibilang statis, nyaris tidak ada pengembangan. Kenyataan ini juga membawa konsekuensi lainnya yakni pembahasan tentang zakat dalam kitab-kitab fiqih, klasik maupun kontemporer selalu ditempatkan pada rumpun ibadah bersamaan dengan shalat, puasa, dan haji, bukan pada rumpun muamalah.

Sementara itu, posisi zakat sebagai mu'amalah maliyah ijtima'iyyah berkaitan erat dengan fungsinya sebagai salah satu jaring pengaman sosial dalam Islam. Pada titik ini, zakat yang berfungsi sebagai salah satu instrumen distribusi kekayaan diharapkan dapat memenuhi kebutuhan dasar orang-orang miskin dan kaum termarjinalkan lainnya. Sehingga dengan sendirinya ketimpangan kekayaan dan pendapatan antara orang-orang kaya dan orang-orang miskin dapat diminamilisir.

\section{DAFTAR PUSTAKA}

Ad-Dumaiji, Abdullah. 2017. Konsep Kepemimpinan dalam Islam. Jakarta Timur: Ummul Qura.

Adz-Dzahabi, Imam. 2017. Dosa-Dosa Besar. Jakarta Timur: Ummul Qura.

Al-Bugha, Musthafa Dieb dan Muhyiddin Mitsu. 2017. Al-Wafi Syarah Hadis Arba'in Imam An-Nawawi. Jakarta: Qisthi Press.

Al-Faizin, Abdul Wahid dan Nashr Akbar. 2018. Tafsir Ekonomi Kontemporer Menggali Teori Ekonomi dari Ayat-Ayat al-Qur'an. Jakarta: Gema Insani Pres.

Al-Jazairi, Abu Bakr Jabir. 2006. Ensiklopedi Muslim. Jakarta Timur: Darul Falah.

Al-Kaaf, Abdullah Zaky. 2002. Ekonomi dalam Perspektif Islam. Bandung: Pustaka Setia.

Al-Mawardi, Imam. 2000. Hukum Tata Negara dan Kepemimpinan dalam Takaran Islam. Jakarta: Gema Insani Press.

Amalia, Euis. 2009. Keadilan Distributif dalam Ekonomi Islam Penguatan Peran LKM dan UKM di Indonesia. Jakarta: Rajawali Pers.

Aprianto, Naerul Edwin Kiky. 2017. "Kontruksi Sistem Jaminan Sosial dalam Perspektif Ekonomi Islam." Dalam Economica: Jurnal Ekonomi Islam, Volume 8, Nomor 2: 237-261. Semarang.

Ar-Rifa'i, Muhammad Nasib. 2012. Ringkasan Tafsir Ibnu Katsir Jilid 1. Jakarta: Gema Insani.

2012. Ringkasan Tafsir Ibnu Katsir Jilid 2. Jakarta: Gema Insani.

Ash-Shallabi, Ali Muhammad. 2014. Biografi Umar bin Khattab. Jakarta Timur: Beirut Publishing. 
2017. Biografi Utsman bin Affan. Jakarta Timur: Ummul Qura.

Asy-Syafi'i, Imam. 2017. Al-Umm Kitab Induk Fiqib Islam Jilid 3. Jakarta: Republika Penerbit.

Atabik, Ahmad. 2014. "Peranan Zakat dalam Pengentasan Kemiskinan." Dalam ZISW AF: Jurnal Zakat dan Wakaf, Vol. 2, No. 2, Desember 2015: 339-361. Kudus.

Beik, Irfan Syauqi dan Laily Dwi Arsyianti. 2016. Ekonomi Pembangunan Syariah. Jakarta: Rajawali Pers.

Chapra, M. Umer. 2006. Islam dan Tantangan Ekonomi. Jakarta: Gema Insani Pres.

Departemen Ekonomi dan Keuangan Syariah Bank Indonesia dan P3EI Fakultas Ekonomi Universitas Islam Indonesia. 2016. Pengelolaan Zakat Yang Efektif: Konsep dan Praktik di Berbagai Negara. Jakarta: Departemen Ekonomi dan Keuangan Syariah Bank Indonesia.

Fauzia, Ika Yunita dan Abdul Kadir Riyadi. 2014. Prinsip Dasar Ekonomi Islam Perspektif Maqashid al-Syari'ah. Jakarta: Kencana.

Firmansyah. 2013. "Zakat sebagai Instrumen Pengentasan Kemiskinan dan Kesenjangan Pendapatan." Dalam Jurnal Ekonomi dan Pembangunan, Vol. 21, No. 2: 179- 190. Jakarta.

Huda, Nurul dkk. 2015. Zakat Perspektif Mikro-Makro Pendekatan Riset. Jakarta: Kencana.

Husni, Indra Sholeh. 2020.'Konsep Keadilan Ekonomi Islam dalam Sistem Ekonomi: Sebuah Kajian Konseptual.” Dalam Islamic Economic Journal, Vol. 6, No. 1 Juni: Ponorogo.

Karim, Adiwarman Azwar. 2008. Sejarah Pemikiran Ekonomi Islam. Jakarta: PT. RajaGrafindo Persada.

Khalid, Khalid Muhammad. 2018. Biografi 60 Sahabat Nabi. Jakarta Timur: Ummul Qura.

Khotib, A. Muhyiddin. 2019. Rekonstruksi Fikih Zakat Telaab Komprehensif Fikih Zakat Pendekatan Teoritis dan Metodologi. Malang: Literasi Nusantara.

Latief, Hilman. 2019. Fatwa-Fatwa Filantropi Islam di Indonesia Anotasi Komparasi dan Kompilasi. Yogyakarta: UMY Press.

Mustahal, Ahmad dan Abdullah Kelib. 2017. "Study tentang Pemungutan Zakat Penghasilan Pegawai pada Unit Pengumpul Zakat Kantor Kementerian Agama Kota Salatiga.” Dalam Jurnal Hukum Khaira Ummah, Vo. 12 No. 1: 27-38. Semarang.

Nasution, Mustafa Edwin dkk. 2007. Pengenalan Ekslusif Ekonomi Islam. Jakarta: Kencana.

Nurhasanah, Siti dan Suryani. 2018. "Maksimalisasi Potensi Zakat Melalui Peningkatan Kesadaran Masyarakat." Dalam JEBI Jurnal Ekonomi dan Bisnis Islam), Volume 3, Nomor 2: 185-194. Padang. 
Pratama, Yoghi Citra. 2015. "Peran Zakat dalam Penanggulangan Kemiskinan (Studi Kasus Program Zakat Produktif pada Badan Amil Zakat Nasional)." Dalam The Journal of Taubidinomics, Vol. 1, No. 1: 93-104. Jakarta.

Rohman, Holilur. 2019. Maqasid al-Syari'ah. Malang: Setara Press.

Qardhawi, Yusuf. 2003. Membumikan Syariat Islam Keluwesan Aturan Ilabi untuk Manusia. Bandung: Arasy.

Quthb, Sayyid. 2018. Tafsir Ayat-Ayat Riba. Jakarta Selatan: Wali Pustaka.

Sabiq, Sayyid. 2017. Fiqih sunnah Jilid 2. Jakarta: Republika Penerbit.

Safitri, Junaidi. 2017. “Implementasi Konsep Zakat dalam Al-Qur'an Sebagai Upaya Mengentaskan Kemiskinan di Indonesia." Dalam Mukaddimab: Jurnal Studi Islam, Volume 2, No. 1: 19-42. Yogyakarta.

Sahhatih, Syauqi Ismail. 2007. Penerapan Zakat dalam Bisnis Modern. Bandung: Pustaka Setia.

Sahroni, Oni. 2020. Fikih Muamalah Kontemporer Jilid 4. Jakarta: Republika Penerbit.

Siswanto, Agus dkk. 2020. HRD Syariah Teori dan Implementasi. Jakarta: Gramedia.

Sitopu, Maria Ulfa. 2007. "Zakat dan Perekonomian Umat Islam." Dalam Islam Futura, Vol. VI, No. 2: 51-60. Banda Aceh.

Sudarsono, Heri. 2007. Bank dan Lembaga Kenangan Syariab Deskripsi dan Ilustrasi. Yogyakarta: Ekonisia FE UII.

Syafiq, Ahmad. 2014. "Prospek Zakat dalam Perekonomian Modern." Dalam Jurnal Zakat dan Wakaf, Vol. 1, No. 1: 145-170. Jakarta.

Thoriquddin, Moh. 2015. Pengelolaan Zakat Produktif Perspektif Maqasid al-Syari'ah Ibnu 'Asyur. Malang: UIN-Maliki Press.

Wijaya, Aksin. 2019. Ragam Jalan Memahami Islam. Yogyakarta: IRCiSoD. 